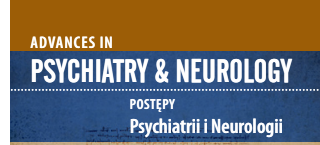

Correspondence to:

Joanna Dymecka Institute of Psychology

University of Opole

Plac Staszica 1

45-052 Opole, Poland

e-mail: jdymecka@uni.opole.pl

Submitted: 15.11 .2019

Accepted: 11.03.2020

\section{ROLE OF RESILIENCY IN \\ THE RELATIONSHIP BETWEEN DISABILITY AND QUALITY OF LIFE OF PEOPLE WITH MULTIPLE SCLEROSIS: MEDIATION ANALYSIS}

\author{
Joanna Dymecka, Rafał Gerymski
}

Institute of Psychology, University of Opole, Opole, Poland

\begin{abstract}
Purpose: Multiple sclerosis (MS) is a chronic progressive demyelinating disease of the central nervous system which leads to permanent disability and affects the health-related quality of life (HRQoL). One of the predictors of HRQoL in people with chronic diseases may be ego resiliency, which is the ability to cope with difficulties in a flexible way. The aim of the study was to determine the relationship between the disability associated with the course of multiple sclerosis and the level of ego resiliency and health related quality of life.

Methods: 110 people diagnosed with MS participated in the study. Guy's Neurological Disability Scale (GNDS), The Resiliency Measurement Scale (SPP-25) and the Multiple Sclerosis Impact Scale 29 (MSIS-29) were used in the study.

Results: The study showed that ego resiliency is a mediator between neurological disability and HRQoL. Neurological disability, which consists of many symptoms of multiple sclerosis, including mood disorders, affects the level of ego resiliency (in the experience of emotions, among others), which affects the mental aspect of health-related quality of life.

Conclusions: The level of ego resiliency is a better predictor of quality of life than the disability itself. This is important from the point of view of clinical practice because an increase in disability is difficult to control while it is possible to develop the level of ego resiliency. The development of resiliency and, associated with this, resources of positive emotionality, can have a positive effect on reducing the impact of the symptoms of the disease on quality of life.
\end{abstract}

Key words: disability, multiple sclerosis, health related quality of life, psychological resilience.

\section{INTRODUCTION}

Multiple sclerosis (MS) is a chronic, progressive, autoimmune disease of the central nervous system, culminating in demyelination and axonal damage in the brain and spinal cord. It is one of the most common neurological diseases in young adults, and the leading cause of non-traumatic disability in young and middle-aged people. MS usually appears between 20 and 40 years of age and its course is as unpredictable as it is highly variable. The clinical manifestation of the disease is related to many neurological disorders, such as mobility problems, sensory and visual disturbances, sphincter disorders, chronic pain, fatigue and cognitive and mood disorders, which lead to the gradual development of disability [1-4].

MS, like many neurological diseases, affects patients' daily functioning and is considered to be a condition that strongly influences health-related quality of life
(HRQoL), defined as the functional effect of the disease and its treatment as perceived by patients [5]. Several features of MS can significantly reduce the quality of life in this population [6]. These include the onset of the disease, which occurs during the most productive years of life, the lack of effective treatment, unpredictable course of the illness and a wide range of symptoms. Additional difficulties are neuropsychiatric complications, which consist of mood and cognitive disorders. Furthermore, the disease appears primarily in young people, negatively affecting their personal development and plans, and threatening their personal autonomy. The unpredictability of its course along with the lack of an effective treatment make it a particular kind of threat to the individual's well-being [7-9]. Some researchers believe that disability is one of the most important factors affecting the quality of life [10], while others indicate the importance of psychological factors [7, 11-13]. 
One of the predictors of the HRQoL in people with chronic diseases may be resiliency, which is the individual's ability to self-regulate cognitive and emotional functioning as well as behavioural control in response to challenges and difficult situations [14]. This is a personality trait which is also a relatively permanent disposition that determines the process of flexible adaptation to constantly changing life events, both traumatic events and everyday occurrences $[15,16]$. Resiliency is considered as a complex resource-supporting way of coping with difficult situations. Ogińska-Bulik and Juczyński [16] perceive resiliency as a theoretical construct consisting of the following features: determination and persistence in actions, openness to new experiences and a sense of humour, competency to cope and tolerance of a negative affect, tolerance of failures and treating life as a challenge, optimistic life attitude and ability to step up in difficult situations.

Resiliency can have a significant impact on the individual's health and affect their ability to cope with chronic illness. MS as an incurable disease which leads to disability can be considered as a chronic and dynamic stressor persisting over time. Diagnosis of MS is associated with an inauspicious change in life, which makes it a source of substantial stress. When a person is struggling with a stressor as strong as MS, resiliency can be a vital resource as it consolidates one's ability to deal with adversities in a dynamic, flexible and creative way, which makes it possible for a person to distance themselves from the negative experiences they are exposed to [14]. It has been in fact demonstrated that people with high levels of resiliency are able to break away from premorbid functioning and build a self-concept that takes the disease into account, which improves their overall quality of life [17]. Besides, resiliency is associated with higher tolerance for negative emotions appearing in the course of chronic illness while it also supports flexible adaptation to the challenges [14] that living with disability presents.

This resource can mediate the relationship between difficult experiences (chronic disease leading to disability) and their adverse psychological effects. It may also play the role of a mediator between a traumatic event and a balanced recovery $[18,19]$, which undoubtedly affects the HRQoL. In addition, people with high level resilien- cy are characterized by the ability to self-regulate properly and dynamically in relation to their adjustment to the difficult situation in which they find themselves $[19,20]$. This process of adaptation to MS is a factor affecting the assessment of quality of life [21]. Therefore, the purpose of the research presented was to determine the relationship between disability associated with MS, resiliency and quality of life. Our hypothesis was that resiliency is a mediator between disability and quality of life. Figure 1 shows the tested mediation model.

\section{METHODS}

The study group consisted of 137 people diagnosed with MS - 73 women and 64 men aged between 18 and $73(\mathrm{M}=46.47 ; \mathrm{SD}=12.59)$. Due to the missing data in the resiliency measuring questionnaire, the final analysis considered the results of 110 people -57 women and 53 men aged between 18 and $73(\mathrm{M}=47.30 ; \mathrm{SD}=13.10)$. These deficiencies arose due to the subsequent attachment to the test battery of the questionnaire for measuring resiliency. Patients with cognitive deficits that impeded the understanding of psychological questionnaires, were excluded from the study (i.e., patients who scored more than 3 points on the Cognitive Disorders subscale of Guy's Neurological Disability Scale [GNDS] questionnaire). The mean duration of MS in the studied sample was 15.10 years $(S D=8.73)$. Characteristics of the patients' disease form and results on the Extended Disability Status Scale are presented in Table 1. As no significant differences in the levels of the tested variables were found between women and men, for the purposes of this manuscript the group was treated as homogeneous (see Table 1).

Four questionnaires were used in the study. The reliability of the methods was verified using Cronbach's $\alpha$ and McDonald's $\omega$ coefficients. The $\omega$ coefficient is a lessbiased estimator of reliability than the traditional $\alpha$ and its assumptions are less restrictive. It can be calculated with e.g. the psych package for R or JAMOVI software.

The first instrument was The Expanded Disability Status Scale (EDSS) by Kurtzke, which is the most commonly used and most popular scale for assessing disability in individuals suffering from MS. The scale includes 20 levels of disability, but in order to make the scoring

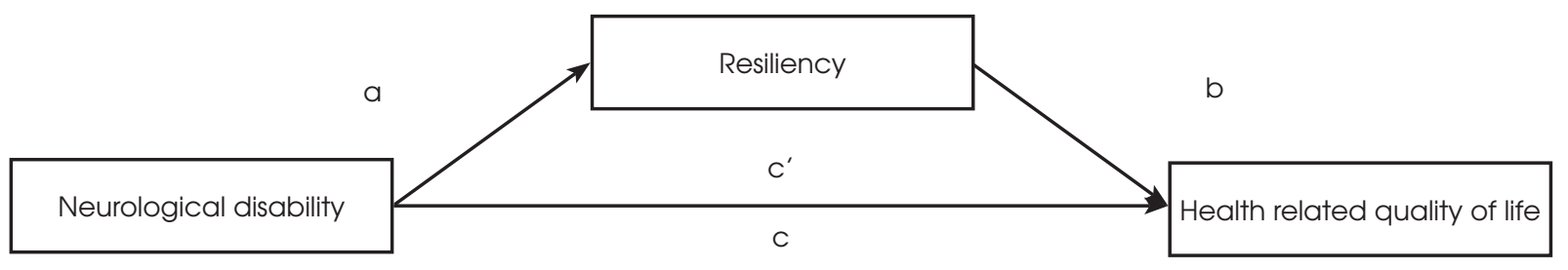

Figure 1. Visualization of the mediation model 
Role of resiliency in the relationship between disability and quality of life of people with multiple sclerosis: mediation analysis

Table 1. Characteristics of the study sample $(N=110)$

\begin{tabular}{|c|c|c|c|c|c|}
\hline Parameter & & & \multicolumn{2}{|c|}{$n$} & $\%$ \\
\hline \multirow{5}{*}{ Form of the illness } & \multicolumn{2}{|c|}{ Relapsing-remitting } & \multicolumn{2}{|c|}{35} & 31.82 \\
\hline & \multicolumn{2}{|c|}{ Primary progressive } & \multicolumn{2}{|c|}{25} & 22.73 \\
\hline & \multicolumn{2}{|c|}{ Secondary progressive } & \multicolumn{2}{|c|}{19} & 17.27 \\
\hline & \multicolumn{2}{|c|}{ Progressive-relapsing } & \multicolumn{2}{|c|}{6} & 5.45 \\
\hline & \multicolumn{2}{|c|}{ Indefinite } & \multicolumn{2}{|c|}{25} & 22.73 \\
\hline \multirow{7}{*}{$\begin{array}{l}\text { Extended Disability Status Scale } \\
(M=4.57 ; S D=2.10)\end{array}$} & \multicolumn{2}{|c|}{$0-4$} & \multicolumn{2}{|c|}{47} & 42.73 \\
\hline & \multicolumn{2}{|c|}{$4.5-5.5$} & \multicolumn{2}{|c|}{20} & 18.18 \\
\hline & \multicolumn{2}{|c|}{$6.0-6.5$} & \multicolumn{2}{|c|}{20} & 18.18 \\
\hline & \multicolumn{2}{|c|}{$7.0-7.5$} & \multicolumn{2}{|c|}{17} & 15.45 \\
\hline & \multicolumn{2}{|c|}{$8.0-9.5$} & \multicolumn{2}{|c|}{5} & 4.56 \\
\hline & Women & Men & \multirow{2}{*}{$t(108)$} & \multirow{2}{*}{$p$} & \multirow{2}{*}{$d_{\text {Cohen }}$} \\
\hline & $M( \pm S D)$ & $M( \pm S D)$ & & & \\
\hline GNDS & $16.8(8.33)$ & $16.4(8.53)$ & -0.23 & 0.816 & 0.04 \\
\hline SPP-25 - summary score & $70.3(13.08)$ & $72.4(12.73)$ & 0.84 & 0.405 & 0.16 \\
\hline MSIS-29 - psychological sphere & $22.9(8.94)$ & $21.5(8.61)$ & -0.88 & 0.380 & 0.17 \\
\hline MSIS-29 - physical sphere & $50.2(18.14)$ & $51.0(17.22)$ & 0.24 & 0.812 & 0.05 \\
\hline
\end{tabular}

consistent with the older version of the scale (DSS), a system of scoring every half point was introduced. The higher the result on the scale, the more severe the disability $[4,22]$. Due to the unsatisfactory psychometric properties of the scale resulting from its structure, it was used to describe the study sample; however, the results were not taken for further analysis.

The Guy's Neurological Disability Scale (GNDS) was used for the assessment of disability and symptoms exhibited by individuals. It consists of 12 subscales concerning separate areas of functioning: cognitive disability, mood disability, visual disability, speech and communication disability, swallowing disability, upper limb disability, lower limb disability, bladder disability, bowel disability, sexual disabilities, fatigue, and other disabilities. Every subscale assesses the disability on 6 levels of severity. Results on separate subscales are summarized in order to describe the patients' overall disability. The higher the score, the more severe the disability [23]. In the presented study, the scale showed good reliability (Cronbach's $\alpha=0.73$, McDonald's $\omega=0.75$ ).

The Resiliency Assessment Scale (SPP-25) by Ogińska-Bulik and Juczyński [16] was used for the assessment of resiliency in all individuals. It consists of 25 items, which form 5 subscales measuring 5 factors: persistence and determination in action, openness to new experiences and sense of humour, personal competences for coping and tolerance of negative affect, tolerance of failure and treating life as a challenge, and optimistic attitude towards life and ability to step up in difficult situations. All items are assessed on a 5-level Likert scale, where 0 indicates strongly disagree, 2 neither agree nor disagree, and 4 strongly agree. Results are calculated for the whole scale and for separate subscales. The higher the score, the higher the levels of mental resiliency. In this study, the SPP-25 questionnaire showed very good psychometric properties (Cronbach's $\alpha=0.93$, McDonald's $\omega=0.94$ ).

The Multiple Sclerosis Impact Scale 29 (MSIS-29) by Hobart and Thompson was used to measure the HRQoL. It was adapted to Polish by Jamroz-Wiśniewska et al. [24]. The scale consists of 29 questions: 20 regarding an individual's physical condition and 9 regarding their psychological condition. Participants assess each of the items on a 5-step Likert scale. The higher the score, the higher the impact of MS on one's quality of life. An overall score, as well as scores on particular subscales, can be calculated. The reliability and validity of the Polish version of the scale are satisfactory. Cronbach a coefficients were equal to 0.97 for the physical factor of quality of life and 0.94 for the psychological factor. In the present study, the reliability of the scales confirms their internal consistency for the psychological (Cronbach's $\alpha=0.83$, McDonald's $\omega=0.84$ ) and physical (Cronbach's $\alpha=0.87$, McDonald's $\omega=0.87$ ) subscales.

\section{Procedure}

The tests were administered in a single meeting with each patient, with no time limit imposed and the duration of sessions being adjusted to the psychophysical capacity of our respondents. Patients were asked to give consent to participate in the study prior to its commencement. 
All patients agreed to participate, which was preceded by a short conversation on general topics aimed at reducing anxiety. The study involved the completion of a set of questionnaires, which were always presented to the respondents in the same order. The sample group consisted of patients diagnosed with MS who were undergoing rehabilitation at the John Paul II Rehabilitation Centre for Individuals with Multiple Sclerosis in Borne Sulinowo, as well as people under the care of the association of MS Patients in Głogów and the Twardziele group (located in the Gdańsk-Gdynia-Sopot Tricity area). The research was approved by the Ethics Committee of the Institute of Psychology of the University of Gdańsk, Poland (No. 19/06/2015).

\section{Statistical analyses}

For the purposes of the analyses the significance level $a=0.05$ was adopted. Pearson's $r$ correlation was used to verify the relationship between variables. The mediation analyses were verified using macro PROCESS v3.4 [25]. Analyses were made using the IBM SPSS 24 software.

\section{RESULTS}

First, the relationship between the studied variables was verified using Pearson's $r$ correlation. All tested re- lationships showed signs of statistically significant correlations. Neurological disability was associated with resiliency in a negative and moderate way, and also with the impact of MS on both spheres of quality of life in a positive, strong way. Resiliency was associated with a negative and moderate impact of MS on the psychological and physical spheres of the quality of life. The exact data is shown in Table 2.

To verify the role of resiliency as a mediator of the relation between neurological disability and HRQoL, the macro PROCESS v3.4 was used [25]. The bootstrapping method was used with the declared number of 5000 samples [26]. Due to the dual nature (psychological and physical) of HRQoL, the analysis using model 4 was performed twice. Model 4 allows for the testing of the significance of the mediation model with one independent variable, one mediator and one dependant variables [25].

The analyses of the indirect effect's confidence intervals for both tested models showed that resiliency was a significant mediator in the relationship between neurological disability and the impact of MS on quality of life in the psychological sphere $\left[\mathrm{a}^{*} \mathrm{~b}=0.07 ; S E=0.04\right.$; $\mathrm{LLCI}=0.018$; ULCI $=0.139]$, but not the physical sphere $\left[\mathrm{a}{ }^{*} \mathrm{~b}=0.01 ; S E=0.04 ; L L C I=-0.068 ; U L C I=0.098\right]$. Table 3 provides more data from this analysis.

Table 2. Results of the Pearson's r correlation

\begin{tabular}{|l|c|c|c|c|c|c|}
\hline \multirow{2}{*}{ Parameter } & \multicolumn{2}{|c|}{ GNDS } & \multicolumn{2}{c|}{ SPP } & \multicolumn{2}{c|}{ MSIS - psychological sphere } \\
\cline { 2 - 7 } & $\boldsymbol{r}$ & $\boldsymbol{p}$ & $\boldsymbol{r}$ & $\boldsymbol{p}$ & $\boldsymbol{r}$ & $\boldsymbol{p}$ \\
\hline SPP & -0.26 & 0.007 & - & - & - & - \\
\hline MSIS - psychological sphere & 0.51 & $<0.001$ & -0.38 & $<0.001$ & - & - \\
\hline MSIS - physical sphere & 0.68 & $<0.001$ & -0.21 & 0.034 & 0.55 & $<0.001$ \\
\hline
\end{tabular}

GNDS - neurological disability, SPP - resiliency, MSIS - MS impact on HRQOL, $r$ - Pearson's correlation coefficient, $p$ - probability value
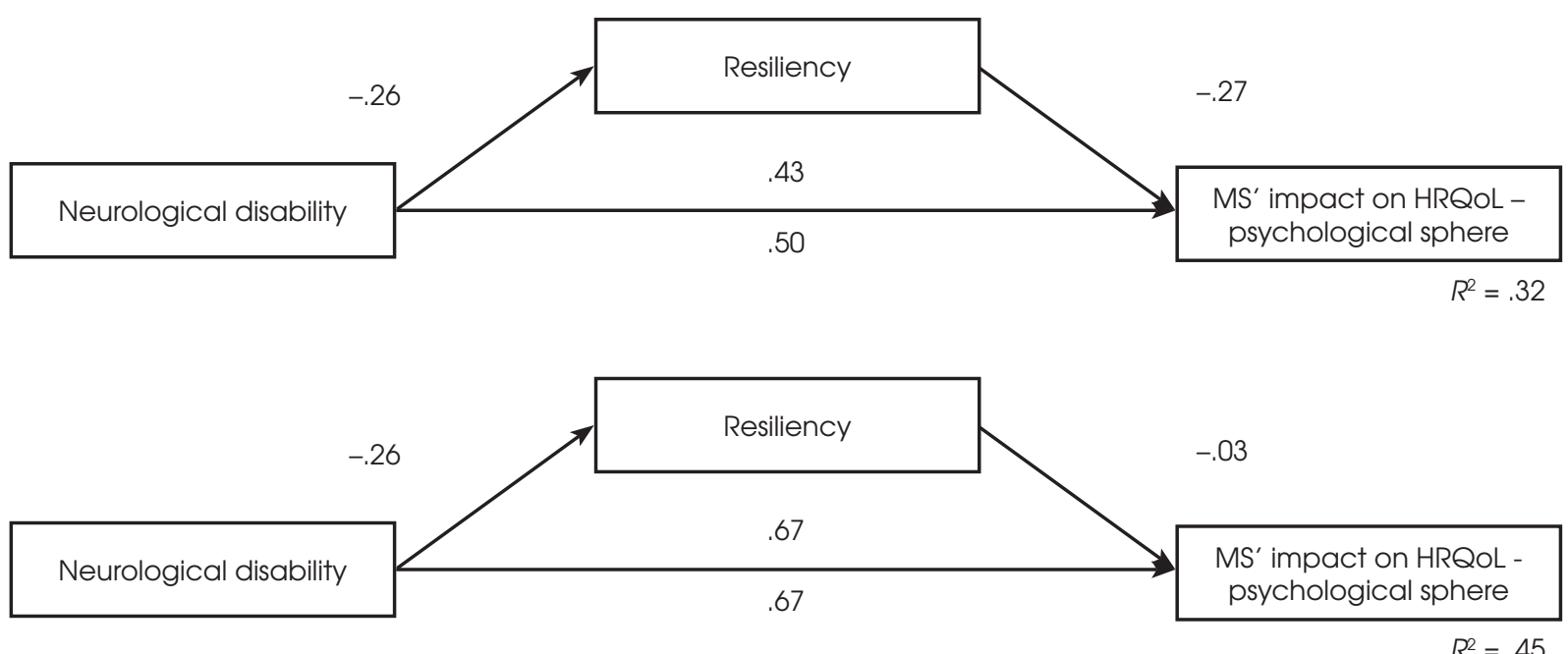

Figure 2. Results of the mediation analyses 
Role of resiliency in the relationship between disability and quality of life of people with multiple sclerosis: mediation analysis

Table 3. Mediation analyses using macro PROCESS v3.4 - detailed data

\begin{tabular}{|c|c|c|c|c|c|c|c|}
\hline MS impact on HRQoL & Path & $\beta$ & SE & $t$ & $p$ & $\mathrm{LLCl}$ & ULCI \\
\hline \multirow{4}{*}{ Psychological sphere } & $X->M(a)$ & -0.26 & 0.14 & -2.76 & 0.007 & -0.678 & -0.111 \\
\hline & $M->Y(b)$ & -0.27 & 0.06 & -3.24 & 0.002 & -0.293 & -0.071 \\
\hline & $X->Y(c)$ & 0.50 & 0.09 & 6.05 & $<0.001$ & 0.354 & 0.698 \\
\hline & $X(M)->Y\left(c^{\prime}\right)$ & 0.43 & 0.09 & 5.27 & $<0.001$ & 0.283 & 0.625 \\
\hline \multirow{4}{*}{ Physical sphere } & $X->M(a)$ & -0.26 & 0.14 & -2.76 & 0.007 & -0.678 & -0.111 \\
\hline & $M->Y(b)$ & -0.03 & 0.10 & -0.42 & 0.676 & -0.242 & 0.158 \\
\hline & $X->Y(c)$ & 0.67 & 0.15 & 9.50 & $<0.001$ & 1.121 & 1.713 \\
\hline & $X(M)->Y\left(c^{\prime}\right)$ & 0.67 & 0.15 & 9.04 & $<0.001$ & 1.093 & 1.708 \\
\hline
\end{tabular}

$X$ - predictor (neurological disability), M- mediator (resiliency), Y-dependent variable (MS impact on HRQLL), $\beta$ - beta, standardized coefficient, SE - standard error, $t$ - t-statistic, $p$-probability value, $\mathrm{LLCl}$ - lower level confidence intervals, ULCI - upper level confidence intervals

\section{DISCUSSION}

The aim of this study was to verify the role of resiliency as a mediator of the relationship between neurological disability and HRQoL. The analysis showed that resiliency was an important mediator of the relationship between disability and the impact of MS on the mental aspect of HRQoL.

Resiliency is a resource that can affect a person's ability to cope with chronic disease even though the disease itself can affect the level of personal resources. Research on people with chronic diseases like ischemic heart disease, type 1 diabetes and rheumatoid arthritis have shown that the level of psychosocial resources varies depending on the type of the disease [27]. It was also found that the level of resiliency of people with MS is lower compared to the general population and other acquired disability groups $[28,29]$. The current study showed a negative relationship between the neurological disability associated with the course of MS and the level of mental resiliency. It can be assumed that this is the result of the impact of the disease on the ability to cope with everyday situations. In addition, mood disorders that contribute to neurological disability can adversely affect the tolerance of negative emotions, which is an element of resiliency. It is indicated that positive emotions can affect the development of resiliency and increase the probability of attributing a positive meaning to unpleasant events $[30,31]$. It has also been shown that there is a relationship between mood disorders and resiliency $[32,33]$. Research has also found that people with low resiliency often feel anxious and have existential doubts [14], more often respond adversely to various environmental stressors and show a tendency towards mood disorders [34]. People who show low-level resiliency experience symptoms linked to depression, such as a sense of isolation and alienation, tendency to ruminate, intensified neurotic tendencies, inability to enjoy life despite the difficulties encountered, worrying about minor failures [35]. All these can simultaneously affect the quality of patient's life.
The study showed that resiliency is a mediator between neurological disability and the mental aspect of HRQoL. Neurological disability, which consists of many symptoms of MS, including mood disorders, affects the level of resiliency (among others in experiencing emotions), which affects the mental aspect of HRQoL. This means that resiliency mediates the impact of neurological disability on the quality of life. The lack of this relationship for the physical aspect of quality of life can be explained by the smaller role of experienced emotions for assessing this aspect of HRQoL.

The relationship between resiliency and quality of life has been confirmed in many studies on various populations [36, 37], e.g. people addicted to alcohol [37]. Furthermore, the relationship between mental resiliency and life satisfaction was also investigated among people with ischemic heart disease, type 1 diabetes and rheumatoid arthritis [27]. According to the research by OgińskaBulik [36] conducted on a group of young people, resiliency is significantly related to the quality of life. It is associated with psychological well-being and a tendency to experience positive emotions that promote health and improve quality of life. The most important factor of resiliency affecting the quality of life was determination and persistence in actions. In other studies involving a group of patients with diabetes and rheumatoid arthritis, it was found that a higher level of mental resiliency is associated with a greater psychological well-being [38].

The relationship between mental resiliency and quality of life was also demonstrated in the population of people with MS $[28,39,40]$, and it was found that resiliency was a mediator of the relationship between MS symptoms, such as pain and fatigue and quality of life. Moreover, resiliency was a stronger predictor of the quality of life than depression, which indicates the particular importance of this resource in relieving neurological symptoms [40]. Researchers believe that resiliency helps people with MS overcome stressful events, which results in a better quality of life [39].

According to Ogińska-Bulik [36], resiliency can also influence the quality of life indirectly through emotions, 
resources and coping. Resiliency affects the processes of affective regulation and arouses positive emotions, which help people put a distance between themselves and their negative experiences and return to balance. Resiliency also influences the appearance of posttraumatic growth [41]. The use of positive emotions in the coping process leads to a better functioning in stressful situations [42]. This is, among others, due to positive affect reducing the frequency of use of defence mechanisms and occurrence of information distortions [43].

The relationship between resiliency and quality of life can be also explained by the adaptation to the disease, which has been analysed in many other studies, most of which prove that the way a person deals with the disease is an important factor affecting quality of life [44]. It has been shown that psychosocial adaptation to the symptoms of MS was an important factor affecting the quality of life of people with MS [21], and that coping methods play a role in predicting quality of life in this population [45]. Resiliency can accelerate the process of passing through the stages of adaptation [17]. Thanks to resiliency, the individual can persist in the face of illness, have positive beliefs about their own recovery and establish good relationships with medical staff. People who are highly resilient in the face of chronic disease do not use rigid coping strategies but are able to adapt flexibly and therefore find it easier to accept new ways of functioning. Ogińska-Bulik and Juczyński [16] indicate that people with strong resiliency more often use adaptive coping strategies focused on tasks and planning than those focused on emotions and avoidance.

It has also been shown that positive emotionality is an important aid in building satisfying interpersonal relationships, becoming helpful in getting emotional support in a difficult situation which a chronic disease certainly is [15]. In addition, people with high-level resiliency are able to break away from premorbid functioning and build self-concepts taking into account the disease, which also improves their quality of life. Similar results were obtained among people with spinal cord damage in whom high levels of resiliency correlated with life satisfaction [17]. In contrast, people with low-level resiliency may experience problems with adapting to the disease which can affect the treatment and rehabilitation process and reduce their quality of life. This also indicates the possibility of the inverse relationship, i.e. the effect of well-being on the level of resiliency, which would involve the so-called spiral of well-being: better functioning and life satisfaction increasing the level of resources thanks to well-being [36].

Despite obtaining satisfying results, the study is not without its limitations. The mediation models presented are treated as causal, yet the analyses applied do not allow us to make inferences about the direction of the impact of the tested variables. In order to verify the relationships investigated more accurately, more advanced qual- itative longitudinal studies must be performed. Another limitation is that the sample examined was obtained by means of targeted selection. What's more, the study focuses on HRQoL only. It is likely that the mediation model presented might also be used in the case of studies on the psychological and subjective well-being of patients with MS. Also, the study did not look at other factors that might affect the functioning of patients with MS, such as age or comorbidity with other illnesses. What is more, resiliency is an ambiguous concept. Some authors recognize it as a personal resource while others treat it as a process. Some positions in the Polish literature discuss this in terms of resiliency $[16,41]$ or resilience $[46,47]$. The ambiguity of the concept may make it difficult to analyse and compare our findings with other research results. It is worth considering in the studies to follow, the role of symptoms such as depression, cognitive impairment and fatigue in the relationship between disease characteristics, personal resources and quality of life. Depression, especially, is an important symptom of the disease that can affect the relationship between disability, resiliency and quality of life.

In summary, MS is a disease that is associated with severe disability consisting of many neurological symptoms. It affects daily functioning, coping and emotional experience. This study shows that resiliency is a mediator between neurological disability and the mental aspect of quality of life. This means that it is a better predictor of quality of life than the disability itself which is important from the point of view of clinical practice, especially in Poland where access to treatment modifying the course of the illness is difficult, which is why the increase in disability is difficult to control. Therefore, it would be reasonable to add psychological therapy to physical rehabilitation to help patients develop higher level of resiliency. This can be done by helping them have new experiences, deal with difficulties effectively, experience positive emotions or develop new skills in proactive coping [48]. Research suggests that the development of resiliency and associated positive emotionality can reduce the impact of the symptoms on quality of life. Whether lower resiliency predisposes a person with a disability to depression is unknown but if it does, interventions aimed at increasing resiliency may decrease the risk of depression [40].

\section{CONCLUSIONS}

Resiliency is a mediator between neurological disability and the mental aspect of quality of life. This means that resiliency is a better predictor of quality of life than the disability itself. The development of resiliency can positively reduce the impact of the symptoms of the disease on quality of life. It is reasonable to add psychological therapy to physical rehabilitation. 


\section{Conflict of interest}

Absent.

\section{Financial support}

Absent.

\section{References}

1. Baecher-Allan C, Kaskow BJ, Weiner HL. Multiple sclerosis: mechanisms and immunotherapy. Neuron 2008; 97: 742-768.

2. Cross AH, Cross KA, Piccio L. Update on multiple sclerosis, its diagnosis and treatments. Clin Chem Lab Med 2012; 50: 1203-1210.

3. Nylander A, Hafler DA. Multiple sclerosis. J Clin Invest 2012; 122: 1180-1188.

4. Selmaj K. Stwardnienie rozsiane. Poznań: Termedia Wydawnictwo Medyczne; 2006.

5. Schipper H. Quality of life: principles of the clinical paradigm. J Psychosoc Oncol 1990; 8: 171-185.

6. Rothwell PM. Quality of life in multiple sclerosis. J Neurol Neurosurg Psychiatry 1998; 65: 433.

7. Benito-León J, Morales JM, Rivera-Navarro J, Mitchell A. A review about the impact of multiple sclerosis on health-related quality of life. Disabil Rehabil 2003; 25: 1291-1303.

8. Boeije HR, Duijnstee MS, Grypdonck MH, Pool A. Encountering the downward phase: biographical work in people with multiple sclerosis living at home. Soc Sci Med 2002; 55: 881-893.

9. Mitchell AJ, Benito-León J, González JM, Rivera-Navarro J. Quality of life and its assessment in multiple sclerosis: Integrating physical and psychological components of wellbeing. Lancet Neurol 2005; 4: 556-566.

10. Tadić D, Dajić V. Quality of life in patients with multiple sclerosis in Republic of Srpska. Med Glas (Zenica) 2013; 10: 113-119.

11. Fischer JS, LaRocca NG, Miller DM, Ritvo PG, Andrews PG, Paty D. Recent developments in the assessment of quality of life in multiple sclerosis (MS). Mult Scler 1999; 5: 251-259.

12. Kikuchi H, Mifune N, Niino M, Kira J, Kohriyama T, Ota K, et al. Structural equation modeling of factors contributing to quality of life in Japanese patients with multiple sclerosis. BMC Neurol 2013; 13: 10.

13. Morales-Gonzáles JM, Benito-León J, Rivera-Navarro J, Mitchell AJ; GEDMA Study Group. A systematic approach to analyse health-related quality of life in multiple sclerosis: the GEDMA study. Mult Scler 2004; 10: 47-54.

14. Block J, Kremen AM. IQ and ego-resiliency: conceptual and empirical connections and separateness. J Pers Soc Psychol 1996; 70: 349-361.

15. Ogińska-Bulik N. Rola prężności w zapobieganiu negatywnym skutkom stresu zawodowego. In: Golińska L, Bielawska-Batorowicz E (eds.). Rodzina i praca w warunkach kryzysu. Łódź: Wydawnictwo Uniwersytetu Łódzkiego; 2011, p. 485-498.

16. Ogińska-Bulik N, Juczyński Z. Skala Pomiaru Prężności (SPP-25). Nowiny Psychologiczne 2008; 3: 39-56.

17. White B. Driver S, Warren AM. Resilience and indicators of adjustment during rehabilitation from a spinal cord injury. Rehab Psychol 2010; 55: 23-32.

18. Bonanno GA, Galea S, Bucciarelli A, Vlahov D. What predicts psychological resilience after disaster? The role of demographics, resources, and life stress. J Consult Clin Psychol 2007; 75: 671-682.

19. Ogińska-Bulik N, Michalska P. Type D personality and post-traumatic stress symptoms in adolescents - the mediating role of resilience. Adv Psychiatry Neurol 2019; 28: 241-256.

20. Waugh CE, Fredrickson BL, Taylor SF. Adapting to life's slings and arrows: individual differences in resilience when recovering from an anticipated threat. J Res Pers 2008; 42: 1031-1046.

21. Hyarat SY, Subih M, Rayan A, Salami I, Harb A. Health related quality of life among patients with multiple sclerosis: the role of psychosocial adjustment to illness. Arch Psychiatric Nurs 2019; 33: 11-16.

22. Kurtzke JF. Natural history and clinical outcome measures for multiple sclerosis studies. Why at the present time does EDSS scale remain a preferred outcome measure to evaluate disease evolution? Neurol Sci 2000; 21: 339-341.

23. Dymecka J, Bidzan M, Rautszko R, Bidzan-Bluma I, Atroszko P. Skala Niesprawności Neurologicznej Szpitala Guy jako istotne narzędzie do oceny objawów występujących u osób z SM. Niepełnosprawność - Zagadnienia, Problemy, Rozwiązania 2017; 1: 85-106.

24. Jamroz-Wiśniewska A, Papuć E, Bartosik-Psujek H, Belniak E, Mitosek-Szewczyk K, Stelmasiak Z. Analiza walidacyjna wybranych aspektów psychometrycznych polskiej wersji Skali Wpływu Stwardnienia Rozsianego na Jakość Życia Chorych (MSIS-29). Neurol Neurochir Pol 2007; 41: 215-222.

25. Hayes AF. Introduction to mediation, moderation, and conditional process analysis: a regression-based approach. New York: Guilford Publications; 2017.

26. Preacher KJ, Hayes AF. Asymptotic and resampling strategies for assessing and comparing indirect effects in multiple mediator models. Behav Res Methods 2008; 40: 879-891.

27. Ziarko M. Zmaganie się ze stresem choroby przewlekłej. Poznań: Wydawnictwo Naukowe Wydziału Nauk Społecznych UAM; 2014.

28. Battalio S, Silverman A, Ehde D, Amtmann D, Edwards K, Jensen M. Resilience and function in adults with physical disabilities: an observational study. Arch Phys Med Rehabil 2017; 98: 1158-1164. 
29. Silverman A, Verrall A, Alschuler K, Smith A, Ehde D. Bouncing back again, and again: a qualitative study of resilience in people with multiple sclerosis. Disabil Rehabil 2017; 39: 14-22.

30. Ogińska-Bulik N, Juczyński Z. Osobowość, stres a zdrowie. Warszawa: Difin; 2010.

31. Tugade MM, Fredrickson BL. Resilient individuals use positive emotions to bounce back from negative emotional experiences. J Pers Soc Psychol 2004; 86: 320-333.

32. Catalano D, Chan F, Wilson L, Chiu CY, Muller VR. The buffering effect of resilience on depression among individuals with spinal cord injury: a structural equation model. Rehabil Psychol 2011; 56: 200-211.

33. Gooding PA, Hurst A, Johnson J, Tarrier N. Psychological resilience in young and older adults. Int J Geriatr Psychiatry 2012; 27: 262-270.

34. Block J, Gjerde PF, Block JH. Personality antecedents of depressive tendencies in 18-year-olds: a prospective study. J Pers Soc Psychol 1991; 60: 726-738.

35. Iskra J. Prężność osobowa a obraz siebie. Badania studentów. In: Golińska L, Bielawska-Batorowicz E (eds.). Rodzina i praca w warunkach kryzysu. Łódź: Wydawnictwo Uniwersytetu Łódzkiego; 2011, p. 525-539.

36. Ogińska-Bulik N. Prężność a jakość życia młodzieży. Psychologia Jakości Życia 2010; 1: 233-247.

37. Ogińska-Bulik N. Prężność psychiczna a zadowolenie z życia osób uzależnionych od alkoholu. Alkoholizm i Narkomania 2014; 27: 319-324.

38. Sęk H, Kaczmarek ŁD, Ziarko M, Pietrzykowska E, Lewicka J. Sprężystość psychiczna a dobrostan w chorobie przewlekłej - mediująca rola podmiotowego umocnienia i radzenia sobie. Polskie Forum Psychologiczne 2012; 17: 327-343.

39. Nery-Hurwit M, Yun J, Ebbeck V, Examining the roles of self-compassion and resilience on health-related quality of life for individuals with multiple sclerosis. Disabil Health J 2018; 11: 256-261.

40. Terrill A, Molton I, Ehde D, Amtmann D, Bombardier CH, Smith AE, et al. Resilience, age, and perceived symptoms in persons with long-term physical disabilities. J Health Psychol 2016; 21: 640-649.

41. Kaczmarek , Sęk H, Ziarko M. Sprężystość psychiczna i zmienne pośredniczące w jej wpływie na zdrowie. Przegląd Psychologiczny 2011; 54: 29-46.

42. Kaczmarek Ł. Skala Sprężystości Psychicznej - polska adaptacja Ego Resiliency Scale. Czasopismo Psychologiczne 2011; 17: 263-265.

43. Felcyn-Koczewska M, Ogińska-Bulik N. Rola prężności w rozwoju potraumatycznym osób w żałobie. In: Goliń ska L, Bielawska-Batorowicz E (eds.). Rodzina i praca z perspektywy wyzwań i zagrożeń. Łódź: Wydawnictwo Uniwersytetu Łódzkiego, p. 511-524 [In press].

44. Aronson KJ. Quality of life among persons with multiple sclerosis and their caregivers. Neurology 1997; 48: 74-80.

45. McCabe M. A longitudinal study of coping strategies and quality of life among people with multiple sclerosis. J Clin Psychol Med Settings 2006; 13: 369-379.

46. Junik W. Zjawisko rezyliencji - wybrane problem metodologiczne. In: Junik W (ed.). Resilience. Teoria - badania - praktyka. Warszawa: Parpamedia; 2011, p. 47-66.

47. Borucka A, Ostaszewski K. Koncepcja resilience. Kluczowe pojęcia i wybrane zagadnienia. Medycyna Wieku Rozwojowego 2008; 12 (2 Pt 1): 587-597.

48. Ogińska-Bulik N, Juczyński Z. Prężność u dzieci i młodzieży: charakterystyka i pomiar - polska skala SPP-18. Polskie Forum Psychologiczne 2011; 16: 7-28. 